\title{
Supply chain management of red chili based on the food supply chain network in Yogyakarta Indonesia
}

\author{
Susanawati ${ }^{1,}{ }^{*}$, Yuli Tri Novita Sari ${ }^{1}$, Muhammad Fauzan ${ }^{1}$, and Juwaidah Sharifuddin ${ }^{2}$ \\ ${ }^{1}$ Department of Agribusiness, Faculty of Agriculture, Universitas Muhammadiyah \\ Yogyakarta, Indonesia \\ ${ }^{2}$ Department of Agribusiness and Bioresource Economics, Faculty of Agriculture, \\ Universiti Putra Malaysia, Malaysia
}

\begin{abstract}
This study aims to describe the relationship structure of the red chili supply chain from Kulonprogo to Jakarta and analyze the supply chain management of red chili based on the Food Supply Chain Network (FSCN). A sampling of red chili farmers was carried out in stages, obtaining 80 people. Meanwhile, the sampling of chain actors after farmers used the snowball sampling technique, resulting in 68 people. The supply chain relationship structure of red chili was analyzed descriptively, whereas supply chain management of red chili was analyzed using an FSCN approach. The results revealed that the red chili supply chain structure was formed by three chains consisting of eight actors. All chain actors entered into an unwritten agreement, except for actors in the auction markets. The transaction system employed the scale and payment methods with a delay system. In addition, government support was only provided in the upstream sub-system. Supply chain collaboration that occurred was the mutual openness and reciprocal relationship. The majority of chain actors had utilized communication media of mobile phones, although few of them made transactions by coming directly to the purchase location. The material communicated was related to price, quality, quantity, and time of payment.
\end{abstract}

\section{Introduction}

Indonesia is well-known not only as a significant agrarian country, but also as the largest archipelago in the world. To build its national economy, priority of place has been given to the agricultural sector [1]. Horticulture is one of the agricultural sectors with the potential as a new growth center [2]. Horticulture comprises several types of potential commodities such as vegetables, fruits, ornamental plants, and biopharmaceuticals [3]. One of the horticultural commodities often consumed by the community is red chili. Red chili is a vegetable plant that can be farmed on a large scale in Indonesia due to its tropical area [4]. This commodity has a high demand for domestic consumers and exports to foreign

\footnotetext{
*Corresponding author: susanawati@umy.ac.id
} 
countries [5]. According to [6], most Indonesian people consume fresh, dried, or processed chilies. They also use red chili for seasoning and spices. Apart from being a spice and an appetite stimulant, red chili can also be used as a health therapy ingredient to deal with muscle spasms, rheumatism, and allergies [5].

Specifically, Kulonprogo Regency is one of the regions in Yogyakarta Special Region (DIY) with the largest amount of red chili production in 2016-2020, with an average production of 106,059.06 tons, as displayed in Table 1. This value can provide the highest contribution of $71 \%$ to red chili production in DIY. In addition, the demand for red chili in Kulonprogo does not come only from the region but also from outside the regency and other big cities. Therefore, Kulonprogo is often referred to as a red chili supplier in Java.

Based on Table 1, Panjatan District is one of the largest red chili-producing areas in Kulonprogo, with an average production of 46,271.24 tons. This number has caused Panjatan District to provide the largest contribution to the red chili production in Kulonprogo Regency, which is $43.63 \%$. This condition has led Panjatan District to be determined as the research location.

Table 1. Red chili production in Kulonprogo Regency in 2016-2020.

\begin{tabular}{|c|c|c|c|c|c|c|c|}
\hline \multirow[t]{2}{*}{ District } & \multicolumn{5}{|c|}{ Year (Tons) } & \multirow{2}{*}{$\begin{array}{c}\text { Average } \\
\text { (Tons) }\end{array}$} & \multirow{2}{*}{$\begin{array}{c}\text { Contribution } \\
(\%)\end{array}$} \\
\hline & 2016 & 2017 & 2018 & 2019 & 2020 & & \\
\hline Temon & 1,665 & 17,721 & 42,999 & $4,089.5$ & $2,847.4$ & $13,864.38$ & 13.07 \\
\hline Wates & 5,006 & 53,510 & 59,729 & $4,952.7$ & $7,363.8$ & $26,112.3$ & 24.62 \\
\hline Panjatan & 9,813 & 94,039 & 104,847 & 9,915.1 & $12,742.1$ & $46,271.24$ & 43.63 \\
\hline Galur & 882 & 17,835 & 23,774 & $2,993.5$ & $5,194.4$ & $10,135.78$ & 9.56 \\
\hline Lendah & 110 & 5,830 & 10,776 & $1,259.5$ & 997.4 & $3,794.58$ & 3.58 \\
\hline Sentolo & 213 & 1,703 & 2,521 & 263.6 & 418 & $1,023.72$ & 0.97 \\
\hline Pengasih & 466 & 5,108 & 4,253 & 549.9 & 589.4 & $2,193.26$ & 2.07 \\
\hline Kokap & 95 & 2,010 & 1,946 & 238.2 & 564.7 & 970.78 & 0.92 \\
\hline Girimulyo & 18 & 152 & 626 & 65.3 & 203.3 & 212.92 & 0.2 \\
\hline Nanggulan & 327 & 2,905 & 154 & 68.5 & 100 & 710.9 & 0.67 \\
\hline Kalibawang & 129 & 887 & 1,730 & 66 & 345.1 & 631.42 & 0.6 \\
\hline Samigaluh & 83 & 148 & 266 & 31.9 & 160 & 137.78 & 0.13 \\
\hline Total & 18,805 & 201,848 & 253,621 & $24,493.7$ & $31,525.6$ & $106,059.06$ & 100 \\
\hline
\end{tabular}

Source: [7]

Although chili is not a staple food, its high consumption in Indonesia, given its use in daily cooking, indicates that it is a high demand commodity. Gaging the relationship between consumer demand and availability, the price of chilies is likely to fluctuate and thereby impact the national economy [8]. Fluctuations in the red chili price make this commodity difficult to predict, causing the market's uncertain supply, including the market in Jakarta. Hence, Panjatan District has made an effort to solve red chili price fluctuations by establishing an auction market. With the auction market, farmers are expected to change the habit of producing red chili at a specific time and amount. If this habit is not changed, it will hinder the red chili distribution.

The red chili distribution system, including in Kulonprogo Regency, will work well if all parties understand the flow of product, money, and information. An optimum flow of product, money, and information of red chili can be the key to the success of the distribution system. In optimizing the red chili distribution, each farming business must pay attention to the supply chain structure in the supply and distribution of the commodity produced. The supply chain can be improved if each actor jointly takes action in obtaining total profit instead of individual profits [9]. This supply chain concept is deemed necessary for all supply chain actors because the supply of red chili from the Panjatan District has 
been used to meet the demand in DIY and Jakarta through Pasar Induk Kramat Jati (PIKJ).

In this case, the supply chain can be defined as the set of relationships between companies or activities, which carry out the supply distribution of the goods or services from the place of origin to the buyers or customers [10]. In the horizontal perspective, there are five major actors in the supply chain: supplier, manufacturer, wholesaler, retailer, and customer [11]. The vertical perspective also comprises five major components of the supply chain: buyer, carrier, warehouse (storage), customer, and seller. The supply chain evolves in three parts [12] the upstream, the internal, and the downstream. [13] claimed that the supply chain is dynamic and covers the flow of information, products, and money at the supply chain level.

Furthermore, the red chili supply chain in Kulonprogo Regency must be managed to run well. Several indicators for supply chain management can also be applied to red chili in Kulon Progo Regency. According to [14], supply chain management can be seen from the aspects of partner selection, transaction system, contractual agreement, government support, and supply chain collaboration, which occur in every supply chain actor. Therefore, this study aims to describe the structure of the red chili supply chain relationship in Kulon Progo Regency, seen from the actors and their activities, and analyze the red chili supply chain management in Kulon Progo Regency, viewed from the aspects of partner selection, contractual agreement, transaction system, government support, and supply chain collaboration.

\section{Research methods}

The primary method used in this research was descriptive analysis. Descriptive analysis is a study conducted to determine variables, either one or more variables, without comparing or connecting one variable to another [15]. It aims to analyze and collect data and make a systematic, factual, and accurate explanation of the facts and characteristics in a particular area.

The location of this research was determined purposively in Kulon Progo Regency because it had the highest production in the Yogyakarta Special Region (DIY), as presented in Table 1. The sampling of red chili farmers in this study was carried out in stages. The first stage was selecting the districts, resulting in Panjatan District because of its highest red chili production in Kulon Progo Regency, as depicted in Table 1.

The second stage was the selection of villages in Panjatan District. Based on the number and members of auction markets, Garongan Village was selected with four auction markets and 285 auction market members. The four auction markets consisted of Bangun Karyo, Jangka Wetan, and Ngudi Asil; in Jangka Wetan, it was still divided into two auction markets due to limited space or the absence of a warehouse for the auction market.

The third stage was selecting hamlets with auction markets, revealing Bangun Karyo's auction market with 115 members, Jangka Wetan with 50 members each, and Ngudi Asil with 70 members. Then, the sample of red chili farmers was determined purposively, resulting in 80 farmers planting red chili in June-August 2019, consisting of 60 farmers from the Bangun Karyo farmer group and 20 farmers from the Ngudi Hasil farmer group.

On the other hand, the sampling technique of supply chain actors after farmers to consumers used snowball sampling. It is a technique for determining the sample, initially small in number, then enlarges [15]. In determining this study sample, the researchers first selected from farmer respondents. Then, the researchers asked the red chili farmers to whom their goods were sold from the farmers who felt that they were still lacking. Therefore, the determination of trader respondents was in accordance with traders who bought red chili from Garongan Village farmers. Then, the researchers obtained information on traders selling red chili to retailers. After that, retailers were asked to 
explain where and to whom they sold red chili to become respondents. Likewise, it continued until the researchers obtained information on the final consumers in Jakarta. Meanwhile, the sample number of chain actors after farmers is displayed in Table 2.

Table 2. Sample of red chili supply chain actors after farmers in Kulonprogo Regency.

\begin{tabular}{|c|l|c|c|}
\hline No. & \multicolumn{1}{|c|}{ Chain Actors } & Total (person) & Location \\
\hline 1. & Auction markets & 1 & Garongan \\
\hline 2. & Middlemen & 2 & Garongan \\
\hline 3. & Collecting traders & 3 & Kulon Progo \\
\hline 4. & Bandar & 3 & PIKJ \\
\hline 5. & $\begin{array}{l}\text { Centeng (a person taking red chili from } \\
\text { a dealer and having a narrow and } \\
\text { sometimes non-permanent place to sell) }\end{array}$ & 10 & PIKJ \\
\hline 6. & Retailers & 20 & Ciracas and PKJ \\
\hline 7. & Consumers & 30 & Ciracas and PKJ \\
\hline
\end{tabular}

The structure of the red chili supply chain relationship was analyzed descriptively in the form of pictures for chain actors and tabular form to describe the activities of each actor. Meanwhile, red chili supply chain management was analyzed based on the Food Supply Chain Network (FSCN) framework, put forward by [16], viewed from the aspects of partner selection, contractual agreement, transaction system, government support, and supply chain collaboration.

\section{Results and discussion}

\subsection{Red chili supply chain relationship structure in Panjatan District, Kulon Progo Regency}

The structure of the red chili supply chain relationship in Kulonprogo Regency was formed by three chains with eight actors, including farmers, auction markets, middlemen, collecting traders, PIKJ bandar, PIKJ centeng, retailers, and consumers. The three chains are:

1. Farmers - intermediaries - collecting traders - PIKJ bandar - PIKJ centeng - retailers consumers

2. Farmers - intermediaries - auction markets - collecting traders - PIKJ bandarPIKJ centeng - retailers - consumers

3. Farmers - auction markets - collecting traders - PIKJ bandar - PIKJ centeng - retailers - consumers

Each actor in the supply chain relationship structure had activities that could facilitate the course of the supply chain. Activities were carried out by actors in the process of producing and distributing red chili from the Kulonprogo Regency to final consumers in Jakarta. Red chili farming carried out by farmers included land processing, seeding, planting, care, and harvesting. After that, farmers sorted the red chili at the time of picking. Then, activities started from sorting, packaging, updating information, and receiving payments in the auction markets. 


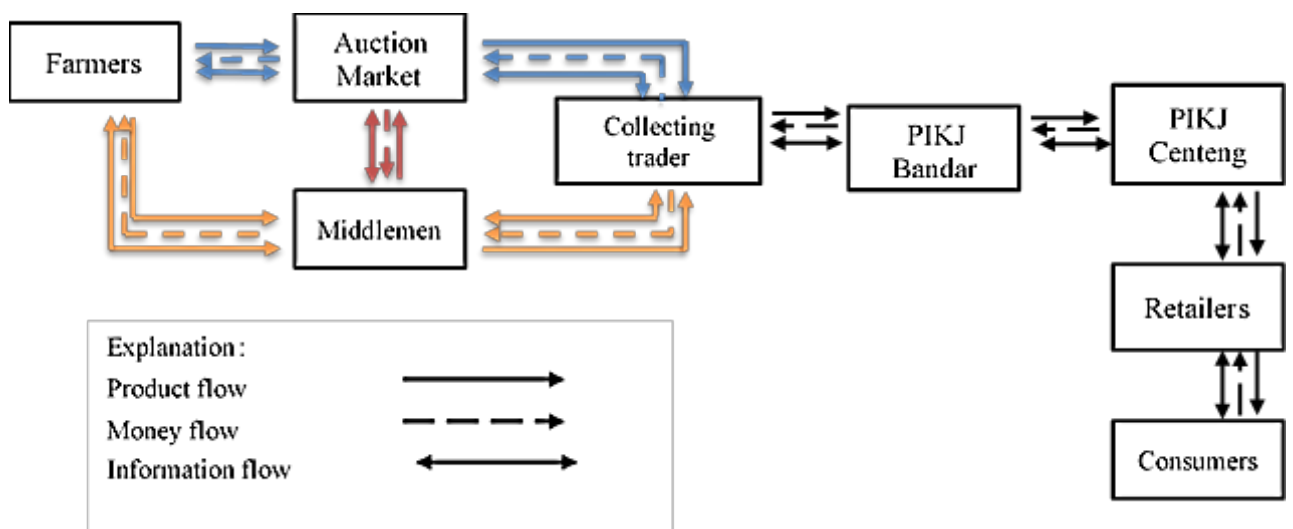

Fig 1. Red Chili Supply Chain Relationship Structure in Kulon Progo Regency Furthermore, intermediaries carried out activities from sorting, packaging, pricing, updating information, purchasing, and receiving payments. Then, collecting traders carried out activities of sorting, packaging, pricing, offering prices, updating information, purchasing, transporting, shipping, and receiving payments. After that, the PIKJ bandar to retailers carried out the same activities, namely packaging, pricing, offering prices, updating information, purchasing, receiving payments, selling, and cleaning red chili. However, at the PIKJ bandar, there was another activity, namely sorting before packing. The last actor was the consumer, who only performed price bidding, purchasing, and cleaning/separating red chili at the time of purchase.

Table 3. Activities of red chili supply chain actors in Kulon Progo Regency.

\begin{tabular}{|c|c|c|c|c|c|c|c|c|c|}
\hline \multirow[b]{2}{*}{ No } & \multirow[b]{2}{*}{ Activities } & \multicolumn{8}{|c|}{ Actors } \\
\hline & & 离 & 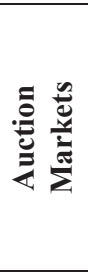 & 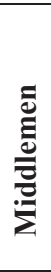 & 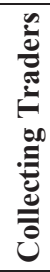 & 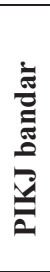 & 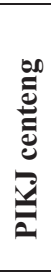 & 这 & 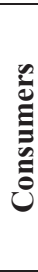 \\
\hline 1 & Red chili farming & $\sqrt{ }$ & - & - & - & - & - & - & - \\
\hline 2 & Sorting & $\sqrt{ }$ & $\sqrt{ }$ & $\sqrt{ }$ & $\sqrt{ }$ & $\sqrt{ }$ & - & - & - \\
\hline 3 & Packaging & - & $\sqrt{ }$ & $\sqrt{ }$ & $\sqrt{ }$ & $\sqrt{ }$ & $\sqrt{ }$ & $\sqrt{ }$ & - \\
\hline 4 & Pricing & - & - & $\sqrt{ }$ & $\sqrt{ }$ & $\sqrt{ }$ & $\sqrt{ }$ & $\sqrt{ }$ & - \\
\hline 5 & Price bidding & - & - & - & $\sqrt{ }$ & $\sqrt{ }$ & $\sqrt{ }$ & $\sqrt{ }$ & $\sqrt{ }$ \\
\hline 6 & Information updates & - & $\sqrt{ }$ & $\sqrt{ }$ & $\sqrt{ }$ & $\sqrt{ }$ & $\sqrt{ }$ & $\sqrt{ }$ & - \\
\hline 7 & Purchasing & - & - & $\sqrt{ }$ & $\sqrt{ }$ & $\sqrt{ }$ & $\sqrt{ }$ & $\sqrt{ }$ & $\sqrt{ }$ \\
\hline 8 & Transporting & - & - & - & $\sqrt{ }$ & - & - & - & - \\
\hline 9 & Shipping & - & - & - & $\sqrt{ }$ & - & - & - & - \\
\hline 10 & Receiving payment & - & $\sqrt{ }$ & $\sqrt{ }$ & $\sqrt{ }$ & $\sqrt{ }$ & $\sqrt{ }$ & $\sqrt{ }$ & - \\
\hline 11 & Sales & - & - & - & - & $\sqrt{ }$ & $\sqrt{ }$ & $\sqrt{ }$ & - \\
\hline 12 & Cleaning/separating & - & - & - & - & $\sqrt{ }$ & $\sqrt{ }$ & $\sqrt{ }$ & $\sqrt{ }$ \\
\hline
\end{tabular}




\subsection{Red Chili Supply Chain Management in Panjatan District in Kulon Progo Regency}

Supply chain management is a method to encourage information systems to manage the procurement of goods and services for companies and establish strategic coordination of traditional business functions between companies in the long-term supply chain [16]. Red chili supply chain management in Kulon Progo Regency based on the Food Supply Chain Network (FSCN) framework was explained through partner selection, contractual agreement, transaction system, government support, and supply chain collaboration, with the following explanation:

\subsubsection{Partner selection}

Partner selection is the process of selecting colleagues to work together in a business [17]. Therefore, it is necessary to select partners following the needs of running a business. It aims to obtain partners and cooperate reasonably. The partner selection carried out by actors in the supply chain structure in this study included:

Table 4. Partner selection by all red chili supply chain actors.

\begin{tabular}{|c|c|c|c|c|c|c|c|c|c|}
\hline \multirow[b]{2}{*}{ No } & \multirow[b]{2}{*}{ Partner Selection } & \multicolumn{8}{|c|}{ Supply Chain Actors } \\
\hline & & 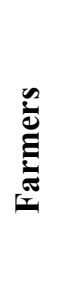 & 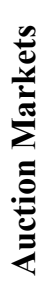 & 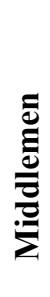 & 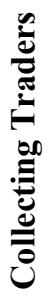 & 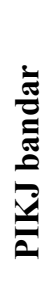 & 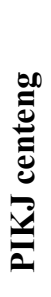 & 苞 & 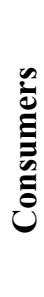 \\
\hline \multirow[t]{7}{*}{1} & \multicolumn{9}{|l|}{ Partner Selection Criteria } \\
\hline & a. High price & $\sqrt{ }$ & - & $\sqrt{ }$ & $\sqrt{ }$ & $\sqrt{ }$ & - & - & - \\
\hline & b. Customers & $\sqrt{ }$ & - & - & $\sqrt{ }$ & $\sqrt{ }$ & $\sqrt{ }$ & $\sqrt{ }$ & - \\
\hline & c. Smooth finances & - & - & $\sqrt{ }$ & $\sqrt{ }$ & - & - & - & - \\
\hline & d. Togetherness & - & - & - & - & - & - & - & - \\
\hline & e. Trust & $\sqrt{ }$ & - & $\sqrt{ }$ & $\sqrt{ }$ & $\sqrt{ }$ & $\sqrt{ }$ & $\sqrt{ }$ & - \\
\hline & f. Business needs & - & - & $\sqrt{ }$ & - & & & & - \\
\hline \multirow[t]{4}{*}{2} & \multicolumn{9}{|l|}{ Partner performance } \\
\hline & a. To be responsible & $\sqrt{ }$ & - & $\sqrt{ }$ & & - & $\sqrt{ }$ & $\sqrt{ }$ & $\sqrt{ }$ \\
\hline & b. Mutually open & $\sqrt{ }$ & $\sqrt{ }$ & $\sqrt{ }$ & $\sqrt{ }$ & $\sqrt{ }$ & $\sqrt{ }$ & $\sqrt{ }$ & $\sqrt{ }$ \\
\hline & c. Satisfaction & - & - & - & $\sqrt{ }$ & $\sqrt{ }$ & - & - & - \\
\hline
\end{tabular}

Table 4 displays that the actors selecting partners due to high prices are farmers, middlemen, collecting traders, and PIKJ bandar. Meanwhile, the actors who did not choose partners based on high prices were PIKJ centeng, retailers, and consumers. The reason why actors did not choose partners based on high prices was that they had been partnered with these actors or became customers, so they only applied a trust system between partners. This result is different from [18] research on the shallot supply chain in Cirebon Regency, where the actor who used the high price criterion in choosing partners was only farmers, whereas the subscription and trust criteria to consumes were selected by 
stalls, PIKJ bandar, and PIKJ centeng. Moreover, actors employed other criteria in partner selection, namely the shallot stalls in Brebes, using the criteria for the suitability of goods. They had been partnering with these partners for a long time. Then, the partners' performance criteria in partnering included responsibility, mutual openness, and satisfaction. The actors felt that their partners had carried out their duties properly and were trustworthy. Actors who applied the criteria of being responsible and open to each other were farmers, auction markets, middlemen, PIKJ centeng, retailers, and consumers.

\subsubsection{Contractual agreement}

A contractual agreement is a contract regarding mutually agreed-upon things between supply chain actors, both written and unwritten [17]. It typically occurs with influential supply chain actors, such as dealers. When it comes to farmers, they rarely make deals because of farmers' lack of knowledge. The following table demonstrates the contractual agreement made by red chili supply chain actors in Panjatan District, Kulon Progo Regency:

Table 5. The contractual agreement of all supply chain actors in Panjatan District, Kulon Progo Regency.

\begin{tabular}{|c|c|c|c|c|c|c|c|c|c|}
\hline \multirow[b]{2}{*}{ No } & \multirow[b]{2}{*}{ Contractual Agreement } & \multicolumn{8}{|c|}{ Supply Chain Actors } \\
\hline & & 莞 & 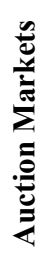 & 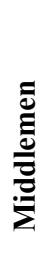 & 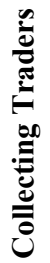 & 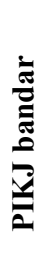 & 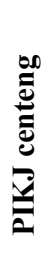 & 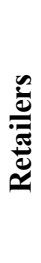 & 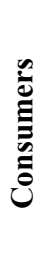 \\
\hline \multirow[t]{3}{*}{1} & Agreement form & & & & & & & & \\
\hline & a. Written & - & - & - & - & - & - & - & - \\
\hline & b. Unwritten & $\sqrt{ }$ & - & $\sqrt{ }$ & - & $\sqrt{ }$ & $\sqrt{ }$ & $\sqrt{ }$ & $\sqrt{ }$ \\
\hline \multirow[t]{12}{*}{2} & Agreed things & & & & & & & & \\
\hline & a. Price & $\sqrt{ }$ & 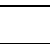 & $\sqrt{ }$ & $\sqrt{ }$ & $\sqrt{ }$ & $\sqrt{ }$ & $\sqrt{ }$ & $\sqrt{ }$ \\
\hline & b. Payment method & $\sqrt{ }$ & - & - & - & $\sqrt{ }$ & - & - & - \\
\hline & c. Cost & $\sqrt{ }$ & - & - & - & - & - & - & - \\
\hline & d. Planting time & $\sqrt{ }$ & - & - & - & - & - & - & - \\
\hline & e. Cropping pattern & $\sqrt{ }$ & - & - & - & - & - & - & - \\
\hline & f. Obligations & $\sqrt{ }$ & - & - & - & - & - & - & - \\
\hline & g. Seeds & $\sqrt{ }$ & - & - & - & - & - & - & - \\
\hline & h. Loan & $\sqrt{ }$ & - & - & - & - & - & - & - \\
\hline & i. Quality & $\sqrt{ }$ & - & $\sqrt{ }$ & - & $\sqrt{ }$ & $\sqrt{ }$ & $\sqrt{ }$ & $\sqrt{ }$ \\
\hline & j. Quantity & $\sqrt{ }$ & - & - & - & $\sqrt{ }$ & $\sqrt{ }$ & $\sqrt{ }$ & $\sqrt{ }$ \\
\hline & k. Payment time & - & - & - & - & & $\sqrt{ }$ & $\sqrt{ }$ & \\
\hline \multirow[t]{9}{*}{3} & Agreement place & & & & & & & & \\
\hline & a. Come to the home & - & - & $\sqrt{ }$ & - & - & - & - & - \\
\hline & b. Farmer & $\sqrt{ }$ & - & - & - & - & - & - & - \\
\hline & c. Auction market & $\sqrt{ }$ & - & - & - & - & - & - & - \\
\hline & d. PIKJ & - & - & - & - & - & $\sqrt{ }$ & - & - \\
\hline & e. Kramat Jati Market & - & - & - & - & - & - & - & $\sqrt{ }$ \\
\hline & f. Ciracas Market & - & - & - & - & - & - & - & $\sqrt{ }$ \\
\hline & g. Communication media & - & - & - & - & $\sqrt{ }$ & - & - & - \\
\hline & h. Coming directly & - & - & - & - & - & - & $\sqrt{ }$ & - \\
\hline
\end{tabular}


Table 5 reveals that red chili supply chain actors did not use the written agreement in choosing partners because they were already customers. The things most agreed upon were price, quality, and quantity. In the last criterion, namely the agreement place, the actors mostly came directly to the partners' place in making the contractual agreement. It was intended so that the agreement could be clearly understood between partners, and later there would be no irregularities in carrying out the contractual agreement. These results are the same as in [19] research with the management of the melon commodity supply chain, that the agreement between partners was carried out unwritten. In the study, farmers and traders applied the principle of trust by committing, feeling interdependent, and in need of each other.

\subsubsection{Transaction system}

The transaction system is a way of selling by each actor to the selected partner. In addition, the transaction system can be seen based on the transaction form for each actor. In the red chili supply chain management in Panjatan District, the transaction system had three criteria: the transaction system, the transaction method, and the payment method for each actor. In the transaction system, there were auction criteria and scales. There were cash, delay, and tempo criteria in the transaction method, while in the payment method, there were transfer and non-transfer criteria. This classification aimed to compare actors in conducting transaction systems in the red chili supply chain in Panjatan District, Kulonprogo Regency.

Table 6. Transaction system for all red chili supply chain actors.

\begin{tabular}{|c|c|c|c|c|c|c|c|c|c|}
\hline \multirow[b]{2}{*}{ No } & \multirow[b]{2}{*}{ Transaction System } & \multicolumn{8}{|c|}{ Supply Chain Actors } \\
\hline & & 苞 & 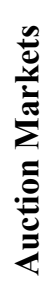 & 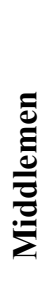 & 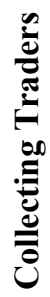 & 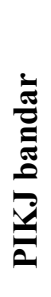 & تِ & 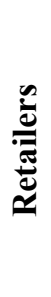 & ن \\
\hline \multirow[t]{3}{*}{1} & \multicolumn{9}{|l|}{ Transaction system } \\
\hline & a. Auction & $\sqrt{ }$ & $\sqrt{ }$ & - & - & - & - & - & - \\
\hline & b. Scale & $\sqrt{ }$ & - & $\sqrt{ }$ & $\sqrt{ }$ & $\sqrt{ }$ & $\sqrt{ }$ & $\sqrt{ }$ & $\sqrt{ }$ \\
\hline \multirow[t]{4}{*}{2} & \multicolumn{9}{|l|}{ Transaction method } \\
\hline & a. Cash & $\sqrt{ }$ & - & $\sqrt{ }$ & - & $\sqrt{ }$ & $\sqrt{ }$ & $\sqrt{ }$ & $\sqrt{ }$ \\
\hline & b. Delay & $\sqrt{ }$ & $\sqrt{ }$ & $\sqrt{ }$ & $\sqrt{ }$ & $\sqrt{ }$ & $\sqrt{ }$ & - & - \\
\hline & c. Tempo & - & - & - & $\sqrt{ }$ & $\sqrt{ }$ & - & - & - \\
\hline \multirow[t]{3}{*}{3} & \multicolumn{9}{|l|}{ Payment method } \\
\hline & a. Transfer & - & - & $\sqrt{ }$ & $\sqrt{ }$ & $\sqrt{ }$ & - & - & - \\
\hline & b. Non-transfer & $\sqrt{ }$ & $\sqrt{ }$ & $\sqrt{ }$ & - & - & $\sqrt{ }$ & $\sqrt{ }$ & $\sqrt{ }$ \\
\hline
\end{tabular}

Table 6 exhibits that most chain actors used a scale transaction system, where they bought and sold to consumers according to the number of scales. The actors who employed the auction transaction system were only red chili farmers and the auction market in Garongan Village. Then, some actors used cash, delay, and tempo criteria in the transaction 
method. The actors who applied the cash system were those buying and selling red chili in small quantities or for household needs and those with large deposits of money. Actors who used cash transactions included farmers, intermediaries, PIKJ bandar, PIKJ centeng, retailers, and consumers.

Meanwhile, the actors who used the delay and tempo systems were farmers, auction markets, middlemen, PIKJ bandar, and PIKJ centeng because they applied a belief system. Furthermore, in terms of payment methods, some actors used transfers and non- transfers. Transfers were made if the actors could not meet directly with partners, while those using non-transfer payment methods were actors who met face-to-face with partners. In another study, [20] uncovered that the transaction system carried out by corn farmers with collecting traders was in cash, while collecting traders and dealers utilized the tempo transaction method, where the dealers paid the collectors within the agreed timeframe.

\subsubsection{Government support}

Government support is one of the supporting systems in the agribusiness development of a commodity. Government support can be in policies and activities from the upstream to the downstream sub-systems and support sub-systems. In classifying government support, there are two criteria: the support form and how it is obtained. On the criteria for support forms, there are criteria for business capital, infrastructure, provision of seeds, and provision of production facilities. Then, there are criteria for obtaining support through programs, proposal submissions, and farmer groups. Government support for all red chili supply chain actors in Kulon Progo Regency can be explained in Table 7.

Table 7. Government support in red chili supply chain management in Kulonprogo Regency.

\begin{tabular}{|c|c|c|c|c|c|c|c|c|c|}
\hline \multirow[b]{2}{*}{ No } & \multirow[b]{2}{*}{ Government Support } & \multicolumn{8}{|c|}{ Supply Chain Actors } \\
\hline & & 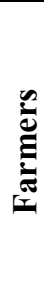 & 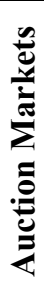 & 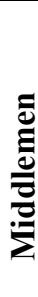 & 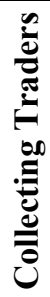 & 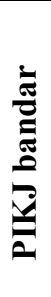 & 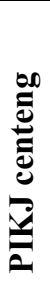 & $\frac{\infty}{0}$ & نَّ \\
\hline \multirow[t]{5}{*}{1} & \multicolumn{9}{|l|}{ Forms of government support } \\
\hline & a. Business capital & $\sqrt{ }$ & - & - & - & - & - & - & - \\
\hline & b. Facilities and infrastructure & $\sqrt{ }$ & $\sqrt{ }$ & - & - & - & - & - & - \\
\hline & c. Provision of seeds & $\sqrt{ }$ & - & - & - & - & - & - & - \\
\hline & d. Provision of production facilities & $\sqrt{ }$ & & - & - & - & - & - & - \\
\hline 2 & \multicolumn{9}{|l|}{ Methods of obtaining support } \\
\hline & a. Through the program & $\sqrt{ }$ & - & - & - & - & - & - & - \\
\hline & b. Submission of proposals & $\sqrt{ }$ & $\sqrt{ }$ & - & - & - & - & - & - \\
\hline & c. Farmer groups & $\sqrt{ }$ & - & - & - & - & - & - & - \\
\hline
\end{tabular}

Table 7 depicts that government support only occurs upstream, namely to farmers and the auction markets. The support forms received by farmers were business capital, infrastructure, seeds, and production facilities. Meanwhile, the auction markets had government support for infrastructure, such as building a warehouse to run the auction market. Then, farmers obtained government support through programs, proposal 
submissions, and farmer groups. Meanwhile, the auction markets attained government support through submitting proposals to the Agriculture Service in the province. Apart from government support, the auction markets also received assistance from private institutions. Meanwhile, in [19] research the government support aimed to improve maize supply chain management, such as maize self-sufficiency, land clearing, fertilizer subsidies, and plans to create agricultural mechanization programs regarding maize. In addition, from the study, Garut Regency has begun to design government support in the marketing field by establishing a Regional Owned Enterprise.

\subsubsection{Supply chain collaboration}

Supply chain collaboration is a collaboration between actors to supply, produce, and distribute products and services to end consumers. If supply chain actors can be open to each other regarding information, a voluntary and reciprocal relationship will be established. Supported by [21] research results, good disclosure of information between supply chain actors is the key to the success of activities in the supply chain. There were four criteria in the supply chain collaboration in the red chili supply chain: information disclosure, communication content, communication media, and communication methods. In information disclosure, there were mutually open and closed criteria. In the communication content, there were criteria for payment time, planting time, price, farmers' needs, variety, quantity, cropping pattern, planting season, seeds, trust, constraints in the auction market, and quality. Then, the communication media used were telephone, SMS, WhatsApp, coming directly, and via taxi bike. Furthermore, the communication methods employed were unidirectional and reciprocal.

Table 8. Red chili supply chain collaboration.

\begin{tabular}{|c|c|c|c|c|c|c|c|c|c|}
\hline \multirow[b]{2}{*}{ No } & \multirow[b]{2}{*}{ Supply Chain Collaboration } & \multicolumn{8}{|c|}{ Supply Chain Actors } \\
\hline & & 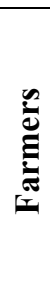 & 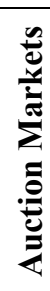 & 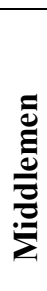 & 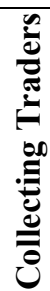 & ت્ & 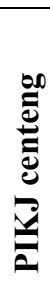 & 递 & 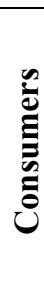 \\
\hline \multirow[t]{3}{*}{1} & \multicolumn{9}{|l|}{ Information disclosure } \\
\hline & a. Mutually open & $\sqrt{ }$ & $\sqrt{ }$ & $\sqrt{ }$ & $\sqrt{ }$ & $\sqrt{ }$ & $\sqrt{ }$ & $\sqrt{ }$ & $\sqrt{ }$ \\
\hline & b. Closed & - & - & - & - & - & - & - & - \\
\hline \multirow[t]{9}{*}{2} & \multicolumn{9}{|l|}{ Communication content } \\
\hline & a. Payment time & $\sqrt{ }$ & - & - & - & $\sqrt{ }$ & $\sqrt{ }$ & $\sqrt{ }$ & - \\
\hline & b. Planting time & $\sqrt{ }$ & - & - & - & - & - & - & - \\
\hline & c. Price & $\sqrt{ }$ & - & - & - & $\sqrt{ }$ & $\sqrt{ }$ & $\sqrt{ }$ & $\sqrt{ }$ \\
\hline & d. Farmers' needs & $\sqrt{ }$ & - & - & - & - & - & - & - \\
\hline & e. Varieties & $\sqrt{ }$ & - & - & - & - & - & - & $\sqrt{ }$ \\
\hline & f. Quantity & $\sqrt{ }$ & $\sqrt{ }$ & - & $\sqrt{ }$ & $\sqrt{ }$ & $\sqrt{ }$ & $\sqrt{ }$ & $\sqrt{ }$ \\
\hline & g. Cropping pattern & $\sqrt{ }$ & - & - & - & - & - & - & - \\
\hline & h. Planting season & $\sqrt{ }$ & - & - & - & - & - & - & - \\
\hline
\end{tabular}




\begin{tabular}{|c|c|c|c|c|c|c|c|c|c|}
\hline \multirow[b]{2}{*}{ No } & \multirow[b]{2}{*}{ Supply Chain Collaboration } & \multicolumn{8}{|c|}{ Supply Chain Actors } \\
\hline & & 离 & 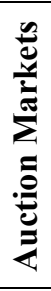 & 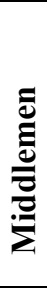 & 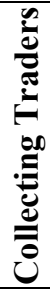 & 国 & 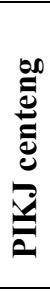 & 苑 & نூ \\
\hline & i. Seeds & $\sqrt{ }$ & - & - & - & - & - & - & - \\
\hline & j. Trust & $\sqrt{ }$ & - & - & - & - & - & - & - \\
\hline & k. Obstacles in the auction market & $\sqrt{ }$ & - & - & - & - & - & - & - \\
\hline & 1. Quality & $\sqrt{ }$ & $\sqrt{ }$ & - & $\sqrt{ }$ & $\sqrt{ }$ & $\sqrt{ }$ & $\sqrt{ }$ & $\sqrt{ }$ \\
\hline 3 & \multicolumn{9}{|l|}{ Communication media } \\
\hline & a. Telephone & $\sqrt{ }$ & $\sqrt{ }$ & $\sqrt{ }$ & - & $\sqrt{ }$ & $\sqrt{ }$ & $\sqrt{ }$ & $\sqrt{ }$ \\
\hline & b. SMS & $\sqrt{ }$ & $\sqrt{ }$ & - & - & & - & - & - \\
\hline & c. WhatsApp & $\sqrt{ }$ & $\sqrt{ }$ & $\sqrt{ }$ & - & $\sqrt{ }$ & $\sqrt{ }$ & $\sqrt{ }$ & - \\
\hline & d. Coming directly & $\sqrt{ }$ & $\sqrt{ }$ & - & - & $\sqrt{ }$ & $\sqrt{ }$ & $\sqrt{ }$ & $\sqrt{ }$ \\
\hline & e. Taxi bike & - & - & - & - & - & - & $\sqrt{ }$ & - \\
\hline \multirow[t]{3}{*}{4} & \multicolumn{9}{|l|}{ Communication methods } \\
\hline & a. Unidirectional & - & - & - & - & - & - & - & - \\
\hline & b. Reciprocal & $\sqrt{ }$ & $\sqrt{ }$ & $\sqrt{ }$ & $\sqrt{ }$ & $\sqrt{ }$ & $\sqrt{ }$ & $\sqrt{ }$ & $\sqrt{ }$ \\
\hline
\end{tabular}

Table 8 illustrates that all red chili supply chain actors carry out information disclosure. Most communication contents used in collaborating were the quantity, quality, and price communication content. The four criteria above were the main things in communicating with partners, except for farmers. Farmers applied communication content more because they were producers. Thus, aside from the four above, the contents used by farmers were also contents about cropping patterns, planting seasons, and constraints in the auction market.

Furthermore, in communicating, most actors utilized communication media of telephone, WhatsApp, or visiting partners directly. In other words, the actors have used technology in cooperating to facilitate collaboration. In the last criterion, the actors communicated with their partners reciprocally. Thus, there was a good response between partners, resulting in no communication errors in the supply chain collaboration. [17], a good supply chain collaboration is the occurrence of activities for each actor smoothly and according to each actor's wishes. Information on the quality and constraints in rice farming from farmers to final consumers was conveyed to farmer groups.

\section{Conclusions and suggestion}

The structure of the red chili supply chain relationship in Kulon Progo Regency was formed by three chains, with eight actors, as follows:

1. Farmers - middlemen - collecting traders - PIKJ bandar - PIKJ centeng - retailers consumers

2. Farmers - middlemen - auction markets - collecting traders - PIKJ bandar PIKJ centeng - retailers - consumers

3. Farmers - auction markets - collecting traders - PIKJ bandar - PIKJ centeng - retailers - consumers 
The red chili supply chain actors in Kulonprogo Regency mostly utilized high price criteria, responsibility, and openness to each other in selecting partners. In the contractual agreement, most chain actors employed the unwritten form, and the things agreed upon were mainly regarding the price, quality, quantity, and payment time. The transaction system for most actors used a scale with delayed payments and by transfer. Besides, government support only occurred in farmers and the auction markets in the form of infrastructure. Supply chain collaboration was through open and reciprocal communication, especially for the price, quality, and quantity with telephone communication media or directly visiting partners.

\section{References}

1. Hamilton-Hart N. J Contemp Asia 49 (5):734-58 (2019).

2. Prapti, K. P., \& Iskandar, R. J. Ilmiah Inovasi, 15(3) (2015).

3. Susanawati, Akhamdi, H., Fauzan, M., and Rozaki, Z. Open Agriculture. 6(1) : 202- 211 (2021).

4. Prayitno, A. B., Hasyim, A. I., and Situmorang, S. JIIA, 1(1) (2013).

5. Sembiring, N. N. Pengaruh Jenis Bahan Pengemas Terhadap Kualitas Produk Cabai Merah (Capsicum Annuum L.) Segar Kemasan Selama Penyimpanan Dingin (Master's thesis) (2019).

6. Taufik, M. (2016). J. Penelitian dan Pengembangan Pertanian 30(2), 66-72 (2016).

7. BPS Kulonprogo. Produksi Tanaman Sayuran dan Tanaman Pangan (2021).

8. Van JC, Huang WC, Anindita R, Chang WI, Yang SH. Scholar J Econ Bus Manag 4(9), 590-9 (2017).

9. Istiyanti, E. \& Kamardiani, DR. Performa Supply Chain Emping Melinjo di Kabupaten Bantul Daerah Istimewa Yogyakarta. AGRARIS: Journal of Agribusiness and Rural Development Research, 3(1), 23-32

10. Assauri S. Manajemen Produksi Dan Operasi. Jakarta, FEUI (2011)

11. Sunny J, Undralla N, Pillai VM. Comput Ind Eng. 150:106895 (2020).

12. Anatan L. J. Karisma 4(2),106-17 (2010)

13. Chopra S, Meidl P. Strategy, planning, and operation. Supply chain management. London, England: Pearson Education International, (2004).

14. Lambert, D. M., \& Cooper, M. C. Industrial Marketing Management 29, 65-83 (2000).

15. Sugiyono. Metode Penelitian Bisnis (Pendekatan Kuantitatif, Kualitatif, Kombinasi dan $R \& D)$. Bandung: Penerbit Alfabet (2013).

16. Van Der Vorst, J. G. Quantifying The Agri-food Supply Chain. Springer Science+Business Media 15, 13-24 (2005) .

17. Qhoirunisa, A.S. Rantai Pasok Padi Di Kabupaten Bogor Provinsi Jawa Barat. Pascasarjana : IPB (2014).

18. Susanawati. Rantai Pasok Pertanian. Yogyakarta: LP3M UMY (2019).

19. Yuniar. Analisis manajemen rantai pasok bunga melati di Kabupaten Karanganyar. Tesis Magister Agribisnis Universitas Sebelas Maret (2012).

20. Hidayat, A., Andayani, S. A., \& Sulaksana, J. J. Ilmu Pertanian dan Peternakan 5(1), 1-13 (2017).

21. Ahmad, S., \& Ullah, A. Interdisciplinary Journal of Contemporary Research in Business 5(7), 39-69 (2013). 